\title{
Digestibility and nitrogen balance of the feed of dairy cows with urea as the sole or partial source of nitrogen
}

\author{
M. Kreula and T. Ettala \\ Biochemical Research Institute, Kalevankatu 56 b, 00180 Helsinki 18, Finland
}

\begin{abstract}
The digestibility and nitrogen balance tests were performed both with cows on purified protein-free feed ( 0 -feed) with urea as the sole source of nitrogen, and with cows on a urea-rich, low-protein diet (ULP-feed). In addition to ordinary low-protein fodders, ULP-feed contained also as the source of energy so-called hemicellulose and 0 -fibre, which are waste products of the cellulose industry.

The determinations were made either with chromic oxide as an indicator, or by collecting the faeces and urine separately.

The average digestibility percentage of the nitrogen $(=$ urea-N) with 0 -cows was $67.0 \pm 5.2$, that of the dry matter $73.9 \pm 5.1$ and that of the organic matter $76.6 \pm 5.1$.

With ULP-cows the average digestibility percentage of the total nitrogen was $71.2 \pm 4.9$ and that of the urea nitrogen varied between 70 and 86 . The average digestibility percentage of hemicellulose was 83 and that of the 0 -fibre of the sulphite cellulose industry (0-fibre 2$) 80$.

The nitrogen balance was positive in all experiments, $+20.4 \pm 20.6 \mathrm{~g}$ with 0 -cows and $+39.4 \pm 16.4 \mathrm{~g}$ with ULP-cows per day.
\end{abstract}

\section{Introduction}

The feeding of urea to dairy cows has been studied at the Biochemical Research Institute under the direction of Professor A. I. Virtanen. In 1961 he started experiments with purified protein-free feed, using starch $(50-55 \%)$, cellulose $(25-30 \%)$ and sugar $(17-23 \%)$ as the sources of energy, and urea and ammonium salts as the sources of nitrogen. This feeding is called 0 -feed and the cows fed in this way are called 0-cows (VIRTANEN 1962, 1963).

In 1966 Virtanen started feeding experiments of a practical nature. In addition to the protein in this feed, urea was given to the cows in amounts providing true protein levels of about 20,40 and $50 \%$ of the digestible crude protein (ULP-feed and ULP-cows). Besides ordinary feed components, waste products of the cellulose industry were used as energy feed: hemicellulose separated from wood and degraded into sugars to a great extent, and socalled 0 -fibre, shortfibred cellulose waste in the wash water. The proportion of these residues in the feed consumed was 15-20\% (VIrTANEN 1967).

Nitrogen balance and digestibility tests were performed with both groups in order to elucidate how much urea and other feed the cows had to be given 
at each production stage to satisfy their protein and energy requirements. In the present report the digestibility and nitrogen balance tests performed during these long-term, two-generation feeding experiments are described.

\section{Methods}

Experiments were performed on both 0- and ULP-feeds. The feeding and production of the cows has been described earlier in several papers (VIRTANEN 1966, 1967; Ettala and Kreula 1976).

The amounts of faeces were measured by using chromium oxide as an indicator or by quantitative collection. In order to determine the nitrogen balance the faeces and urine were either collected together, in which case the amount of the faeces was determined by means of chromium oxide, or separately. The test cow was fed $10 \mathrm{~g} \mathrm{Cr}_{2} \mathrm{O}_{3}$ /day during a period of ten days before the particular test period which lasted for 7-12 days. For the collection of the urine a "Urinal" harness (VEB Leipziger Gummiwarenfabriken) was used.

The content of $\mathrm{Cr}_{2} \mathrm{O}_{3}$ was determined on the faeces according to ANDERSEN (1934). Nitrogen was determined on the feed, faeces, urine and milk by the Kjeldahl method, using $\mathrm{KMnO}_{4}$ (BeEt 1955). Dry matter $\left(105^{\circ} \mathrm{C}, 24 \mathrm{~h}\right)$ and ash were determined on the feed, faeces and milk. Crude fibre was determined on the feed and faeces by the acid-base method applied by HIRSJ

\section{Digestibility and nitrogen balance tests on 0 -feed}

Digestibility tests were performed with all the 0 -cows, and more than once with some of the cows (Table 1). The composition of the feed and the daily amounts of organic matter, urea and nitrogen are also seen in Table 1.

Table 1. The contents of carbohydrates and nitrogen in the feed of the 0 -cows and the daily consumption of organic matter and urea.

\begin{tabular}{|c|c|c|c|c|c|c|c|c|}
\hline \multirow[b]{2}{*}{ Test cow } & \multicolumn{3}{|c|}{ Composition of feed carbohydrates } & \multirow{2}{*}{$\begin{array}{c}\text { In feed } \\
\mathrm{N} \mathrm{g} / \mathrm{kg} \\
\text { org. matter }\end{array}$} & \multirow[b]{2}{*}{$\begin{array}{l}\text { Org. } \\
\text { matter } \\
\text { kg/day }\end{array}$} & \multicolumn{2}{|l|}{ Consumption } & \multirow{2}{*}{$\begin{array}{l}\text { Production } \\
\text { Stand. } \\
\text { milk } \\
\text { kg/day }\end{array}$} \\
\hline & $\begin{array}{c}\text { Starch } \\
\%\end{array}$ & $\begin{array}{c}\text { Cellulose } \\
\%\end{array}$ & $\begin{array}{c}\text { Sugar } \\
\%\end{array}$ & & & $\begin{array}{l}\text { Urea } \\
\text { g/day }\end{array}$ & $\begin{array}{l}\text { Nitrogen } \\
\text { g/day }\end{array}$ & \\
\hline Eiru......... & .. $49.2 \pm 3.7$ & $7.2 \pm 2.8$ & $23.7 \pm 4.6$ & $19.3 \pm 1.9$ & & $346.5 \pm 52.2$ & $159.4 \pm 24.0$ & $6.5 \pm 0.9$ \\
\hline Aino.......... & .. $47.1 \pm 0.5$ & $34.5 \pm 1.1$ & $19.5 \pm 0.6$ & $18.1 \pm 1.6$ & $6.5 \pm 0.8$ & $256.8 \pm 52.5$ & $118.2 \pm 24.1$ & $5.2 \pm$ \\
\hline $\begin{array}{l}\text { Ela .............. } \\
\text { Lairu }\end{array}$ & .. 56.2 & 20.4 & 23.4 & 19.6 & 4.6 & 195.6 & 90.0 & 0 \\
\hline (heifer-cow) .. & .. 59.5 & 15.7 & 24.8 & 19.1 & 4.0 & 168.5 & 77.5 & 0 \\
\hline Jairu .......... & .. $53.4 \pm 3.6$ & $23.4 \pm 4.2$ & $23.2 \pm 0.8$ & $22.1 \pm 2.5$ & $7.5 \pm 0.9$ & $359.2 \pm 43.6$ & $165.2 \pm 20.1$ & 6.8 \\
\hline Metta ......... & .. $56.8 \pm 9.0$ & $26.3 \pm 5.6$ & $16.9 \pm 3.6$ & $23.0 \pm 1.8$ & $7.4 \pm 2.9$ & $374.2 \pm 157.1$ & $172.1 \pm 72.3$ & $6.7 \pm 6.2$ \\
\hline Nairu .......... & .. 54.4 & 22.0 & 23.6 & 28.2 & 8.4 & 513.0 & 236.0 & 8.8 \\
\hline Pairu ........... & .. $58.2 \pm 0.8$ & $16.4 \pm 1.2$ & $25.5 \pm 0.4$ & $29.1 \pm 2.9$ & $7.7 \pm 1.3$ & $480.8 \pm 29.6$ & $221.2 \pm 13.6$ & $6.7 \pm 2.3$ \\
\hline Oona......... & .. $52.1 \pm 1.2$ & $23.3 \pm 2.2$ & $24.7 \pm 1.1$ & $26.0 \pm 2.8$ & $7.9 \pm 1.4$ & $435.7 \pm 115.0$ & $200.4 \pm 52.9$ & $6.6 \pm 2.6$ \\
\hline $\begin{array}{l}\text { Voona .......... } \\
\text { Mean value }\end{array}$ & $. .50 .0 \pm 2.9$ & $25.1 \pm 3.7$ & $25.0 \pm 0.8$ & $22.5 \pm 3.3$ & $6.8 \pm 1.8$ & $339.7 \pm 137.6$ & $156.2 \pm 63.4$ & $4.8 \pm 0$ \\
\hline in all tests... & .. $52.8 \pm 4.7$ & $24.2 \pm 5.0$ & $23.1 \pm 3.2$ & $22.8 \pm 3.8$ & $7.3 \pm 1.5$ & $370.9 \pm 112.8$ & $170.6 \pm 51.9$ & $6.2 \pm 2.8$ \\
\hline
\end{tabular}


The compositions did not differ very much from one another, because only pellets, cellulose-rich paste and cellulose strips were included in the feed (Virtanen 1964, 1966). The proportions of the above three feed components were changed according to the taste preference of each cow. The cows were allowed to drink water ad libitum, but its consumption was measured.

\section{Results and discussion}

The results of the digestibility tests are seen in Table 2. The digestibility percentage of urea nitrogen was on the average $67.0 \pm 5.2$. In 1963-1964 in the first digestibility tests the average digestibility percentage of nitrogen was only 61.8. This may have been due to the fact that the feed then contained less urea than later. At first the amount of nitrogen per $\mathrm{kg}$ organic matter was $18-20 \mathrm{~g}$, out it was raised later to $22-31 \mathrm{~g}$. The nitrogen content of the feed seems to have had the same effect as in the experiments of RALEIGH et al. (1963), who found that with bull calves the digestibility of nitrogen increased considerably when the nitrogen content of the feed was raised.

The digestibility percentage of dry matter was on the average $73.9 \pm 5.1$, that of organic matter $76.6 \pm \mathbf{5 . 1}$ and that of cellulose $54.4 \pm 12.3$. The digestibility of cellulose was comparatively low, because the cellulose powder of the pellets and cellulose paste passed through the rumen partly undigested (VIrTANen 1964). The cellulose included in the feed was bleached sulphite cellulose, which according to SAARINEN et al. (1959) is less digestible than unbleached cellulose.

The results have varied considerably, as can be seen from the standard deviations. The methods used do not seem to have any clear effect on the values obtained. The results obtained by the collection method and by chromium oxide have been consistent. However, it must be remembered that the results were obtained during a period of twelve years, and the milk production of the test cows varied between 0 and $12 \mathrm{~kg}$ per day. Table 1 shows the daily milk production calculated as standard milk on an energy basis (684 Kcal/kg milk).

Table 2. The digestibility of the 0 -feed.

\begin{tabular}{|c|c|c|c|c|c|c|}
\hline \multirow{2}{*}{\multicolumn{3}{|c|}{$\begin{array}{c}\text { Test cow and number } \\
\text { of tests }\end{array}$}} & \multicolumn{4}{|c|}{ Digestibility \% } \\
\hline & & & Dry matter & Organic matter & Nitrogen & Cellulose \\
\hline Eiru & $(4)$ & …………… & $70.6 \pm 3.2$ & $73.4+2.5$ & $67.6 \pm 7.2$ & $46.0 \pm 3.3$ \\
\hline Aino & $(2)$ & .................... & $62.5 \pm 0$ & $66.0 \pm 1.4$ & $63.1 \pm 1.5$ & 45.8 \\
\hline Ela & (1) & .................... & 78.1 & 81.0 & 62.8 & - \\
\hline Lairu & (1) & .................... & 78.1 & 80.9 & 66.8 & 43.3 \\
\hline Jairu & (5) & .................... & $75.4 \pm 3.8$ & $78.4 \pm 3.4$ & $67.8 \pm 4.8$ & $57.9 \pm 16.5$ \\
\hline Metta & (3) & .................... & $74.5 \pm 2.9$ & $76.2 \pm 4.7$ & $66.1 \pm 2.2$ & $63.2 \pm 6.9$ \\
\hline Nairu & $(1)$ & 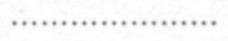 & 65.9 & 66.9 & 62.1 & 45.6 \\
\hline Pairu & $(2)$ & (n.w. & $74.4 \pm 6.1$ & $76.9 \pm 6.2$ & $65.9 \pm 10.1$ & $38.9 \pm 1.1$ \\
\hline Oona & (7) & ................... & $77.1 \pm 3.3$ & $79.8 \pm 3.6$ & $70.1 \pm 3.9$ & $61.8 \pm 13.2$ \\
\hline Voona & $(2)$ & …................. & $75.5 \pm 0.5$ & $77.1 \pm 0.4$ & $63.8 \pm 10.0$ & 67.3 \\
\hline Mean & value & e of all tests ... & $73.9 \pm 5.1$ & $76.6 \pm 5.1$ & $67.0 \pm 5.2$ & $54.4 \pm 12.3$ \\
\hline
\end{tabular}


Table 3. The nitrogen balance on 0 -feed.

\begin{tabular}{|c|c|c|c|c|c|c|}
\hline $\begin{array}{l}\text { Test cow } \\
\text { and number } \\
\text { of tests }\end{array}$ & $\begin{array}{c}\text { Fed } \\
\text { N } \\
\text { g/day }\end{array}$ & $\begin{array}{l}\text { Faeces } \\
\text { N } \\
\text { g/day }\end{array}$ & $\begin{array}{c}\text { Milk } \\
\text { N } \\
\text { g/day }\end{array}$ & $\begin{array}{c}\mathrm{N} \\
\mathrm{g} / \mathrm{day}\end{array}$ & $\%$ dig. $\mathrm{N}$ & $\begin{array}{l}\text { N-balance } \\
\text { g/day }\end{array}$ \\
\hline (2) & $\ldots \ldots . .119 .9 \pm 28.8$ & $48.8 \pm 8.3$ & $18.3 \pm 17.7$ & $40.3 \pm 4.8$ & $57.9 \pm 9.9$ & $+12.9 \pm 2.1$ \\
\hline Aino (1). & ….. 135.2 & 51.4 & 31.8 & 48.0 & 57.3 & +4.0 \\
\hline Jairu (3) . & $\ldots \ldots \ldots 187.7 \pm 11.4$ & $62.2 \pm 11.5$ & $45.3 \pm 12.2$ & $65.3 \pm 3.2$ & $52.0 \pm 2.2$ & $+14.1 \pm 9.9$ \\
\hline Metta (1). & $\ldots \ldots \ldots 223.5$ & 72.8 & 45.3 & 93.2 & 61.8 & +12.2 \\
\hline Nairu (1) & ...... 236.0 & 89.3 & 50.0 & 91.0 & 62.0 & +5.7 \\
\hline Pairu (1) & ...... 230.8 & 95.3 & 39.8 & 94.0 & 69.4 & +1.8 \\
\hline Oona (7) & $\ldots \ldots .200 .4 \pm 52.9$ & $59.2 \pm 15.2$ & $32.8 \pm 12.4$ & $69.1 \pm 18.1$ & $49.9 \pm 6.9$ & $+38.3 \pm 22.9$ \\
\hline Voona (1) . & ...... 111.4 & 48.2 & 26.4 & 32.0 & 50.6 & +4.8 \\
\hline $\begin{array}{l}\text { Mean value } \\
\text { in all tests }\end{array}$ & $\ldots \ldots 182.0 \pm 49.6$ & $61.7 \pm 15.8$ & $36.0 \pm 13.2$ & $65.3 \pm 20.5$ & $54.2 \pm 7.4$ & $+20.4 \pm 20.6$ \\
\hline
\end{tabular}

Table 4. The amount of ash in the feed, faeces, urine and milk of cows.

\begin{tabular}{|c|c|c|c|c|c|}
\hline Test c & $\begin{array}{l}\text { cow and number } \\
\text { of tests }\end{array}$ & $\begin{array}{c}\text { Fed } \\
\text { g/day }\end{array}$ & $\begin{array}{c}\text { Faeces } \\
\text { g/day }\end{array}$ & $\begin{array}{c}\text { Ash } \\
\text { Urine } \\
\text { g/day }\end{array}$ & $\begin{array}{l}\text { Milk } \\
\text { g/day }\end{array}$ \\
\hline Eiru & 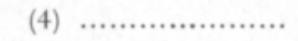 & $653.0 \pm 99.2$ & $405 \pm 120$ & & \\
\hline Aino & (2) $\ldots \ldots \ldots \ldots \ldots \ldots \ldots \ldots$ & $602.5 \pm 24.7$ & $447 \pm 60$ & & \\
\hline Ela & 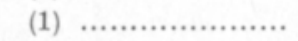 & 380 & 205 & & \\
\hline Lairu & 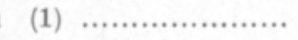 & 355 & 190 & & \\
\hline Jairu & (3) $\ldots \ldots \ldots \ldots \ldots \ldots \ldots \ldots$ & $658.0 \pm 53.1$ & $392 \pm 96$ & 160 & 50 \\
\hline Metta & 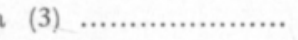 & $733.3 \pm 286.0$ & $380.0 \pm 147.7$ & 275 & 55 \\
\hline Nairu & (1),$\ldots \ldots \ldots \ldots \ldots \ldots \ldots \ldots \ldots \ldots \ldots$ & 635 & 320 & & \\
\hline Pairu & (2) & $710.0 \pm 63.6$ & $360 \pm 99$ & & \\
\hline Oona & (7) $\ldots \ldots \ldots \ldots \ldots \ldots \ldots \ldots$ & $674.7 \pm 1055$ & $365 \pm 100$ & $148 \pm 9$ & $38.8 \pm 16$ \\
\hline Mean & value in all tests .. & $631.4 \pm 146.0$ & $357.9 \pm 113.4$ & $160.0 \pm 52.0$ & $43.0 \pm 12.0$ \\
\hline
\end{tabular}

It is obvious that there were differences between individual cows as regards the capacity to digest the feed. Schiemann et al. (1974) found highly significant between-cow differences in this respect. Various taste preferences have also caused such differences between individual cows. In test cow Aino, which preferred cellulose-rich feed, the digestibility percentages were considerably lower than in the other cows, that is the digestibility of dry matter, organic matter and nitrogen as well. Some of the cows were so much disturbed by the arrangements for the test that they did not consume all the feed. The result was in many cases a decrease in the digestibility of the feed.

The results of the nitrogen balance test are given in Table 3 . In all the tests the nitrogen balance was positive and high. This means that the cows on urea feed received nitrogen in amounts corresponding to the requirement for production or even more, in which case their weight rose.

Table 4 gives the amounts of ash in the feed and in the faeces. In some cases also the ash contents in the milk and urine were determined. The amount of ash in the faeces was on the average $50 \%$ of that of the feed. 


\section{Digestibility tests on ULP-feed}

The feed of the ULP-cows contained dried sugar beet pulp, potatoes, oats, dried hemicellulose syrup, 0 -fibre, a little straw, fat soluble vitamins and urea to make good the deficiency in protein (VIRTANEN 1967, 1972; EtTALA and KREUla 1976). To satisfy the mineral requirement the ULP-cows received the same mineral mixture as the 0 -cows in addition to the minerals of the feed (VIRTANEN 1966).

As the ULP-cows were fed hemicellulose and 0 -fibre, the digestibility of which was unknown to us, a series of tests was arranged to begin with, in which the digestibility of the sugar beet pulp was first determined. Based on the values obtained the digestibility of hemicellulose and various 0 -fibres was then determined (Table 5). In addition, digestibility tests were performed with three cows 11 months, 3,4 and 8 years after the start of the experiments, while they were being fed their usual test feed (Table 6).

Table 5. Preliminary tests for the determination of the digestibility of sugar beet pulp, hemicellulose and 0 -fibre.

$\begin{array}{llllll}\text { Test } 1 & \text { Test } 2 & \text { Test } 3 & \text { Test } 4 & \text { Test } 5 & \text { Test } 6\end{array}$

Feed combination

\begin{tabular}{|c|c|c|c|c|c|c|c|}
\hline Sugar beet pulp, & $\% /$ d.m. & ........... & 92.7 & 68.8 & 73.1 & 68.3 & 70.9 \\
\hline Hemicellulose & 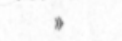 & .......... & 0 & 24.0 & 0 & 0 & 0 \\
\hline Sucrose & , & .......... & 0 & 0 & 17.8 & 7.4 & 7.4 \\
\hline 0 -fibre 1 & , & .......... & 0 & 0 & 0 & 15.9 & 0 \\
\hline 0 -fibre 2 & , & ........... & 0 & 0 & 0 & 0 & 14.0 \\
\hline Urea & , & .......... & 4.0 & 4.1 & 4.4 & 4.0 & 3.9 \\
\hline Mineral mixture & , & …...... & 2.8 & 2.7 & 4.3 & 3.9 & 3.8 \\
\hline Vegetable oil & , & ........... & 0.5 & 0.4 & 0.4 & 0.4 & 0 \\
\hline
\end{tabular}

Fed

Total dry matter, $\mathrm{kg}$............... $\quad 6.2$

Organic matter, kg ................. $\quad 5.6$

Protein, g N/day .................. 218.9

$\begin{array}{rrrrr}6.6 & 6.8 & 7.4 & 6.8 & 6.1 \\ 5.9 & 6.0 & 6.6 & 6.1 & 5.4 \\ 207.5 & 225.0 & 225.0 & 196.6 & 146.3\end{array}$

$\mathrm{N}, \mathrm{g} / \mathrm{kg}$ organic matter $\ldots \ldots \ldots \ldots . .39 .1$

Urea-N, \%/total N ................ 53.4

35.1

37.5

$$
34.0
$$

$32.2 \quad 26.9$

Crude fibre, $\%$ of dry matter... -

60.8

61.6

\section{Digestibility}

$\%$

Dry matter

Organic matter .................... 67.5

Nitrogen ............................. 79.8

Nitrogen-free extracts ........... 88.0

88.0

-

Crude fibre

$\%$

67.7

$\%$

67.1

69.9

$\%$

66.5

$\%$

$\%$

79.4

69.7

66.2

81.2

80.3

84.1

Hemicellulose

0 -fibre 2

Production as standard milk, $\mathrm{kg} /$ day 4 
The cows' digestibility percentages differed from one another, as did those of cow Lila in various tests. This may be due to differences in the choice of feed. The later tests with Lila gave considerably higher values than the first test, when the feed contained relatively large amounts of 0 -fibre 1 , the digestibility of which was only $50 \%$ (Table 7). The digestibility of nitrogen on ULP-feed seemed to vary between 65 and $75 \%$. The digestibility percentage of urea nitrogen was $70-86$, while the digestibility of the other feed protein was calculated from tabulated figures.

Table 6. The composition and consumption of the feed combinations of ULP-cows

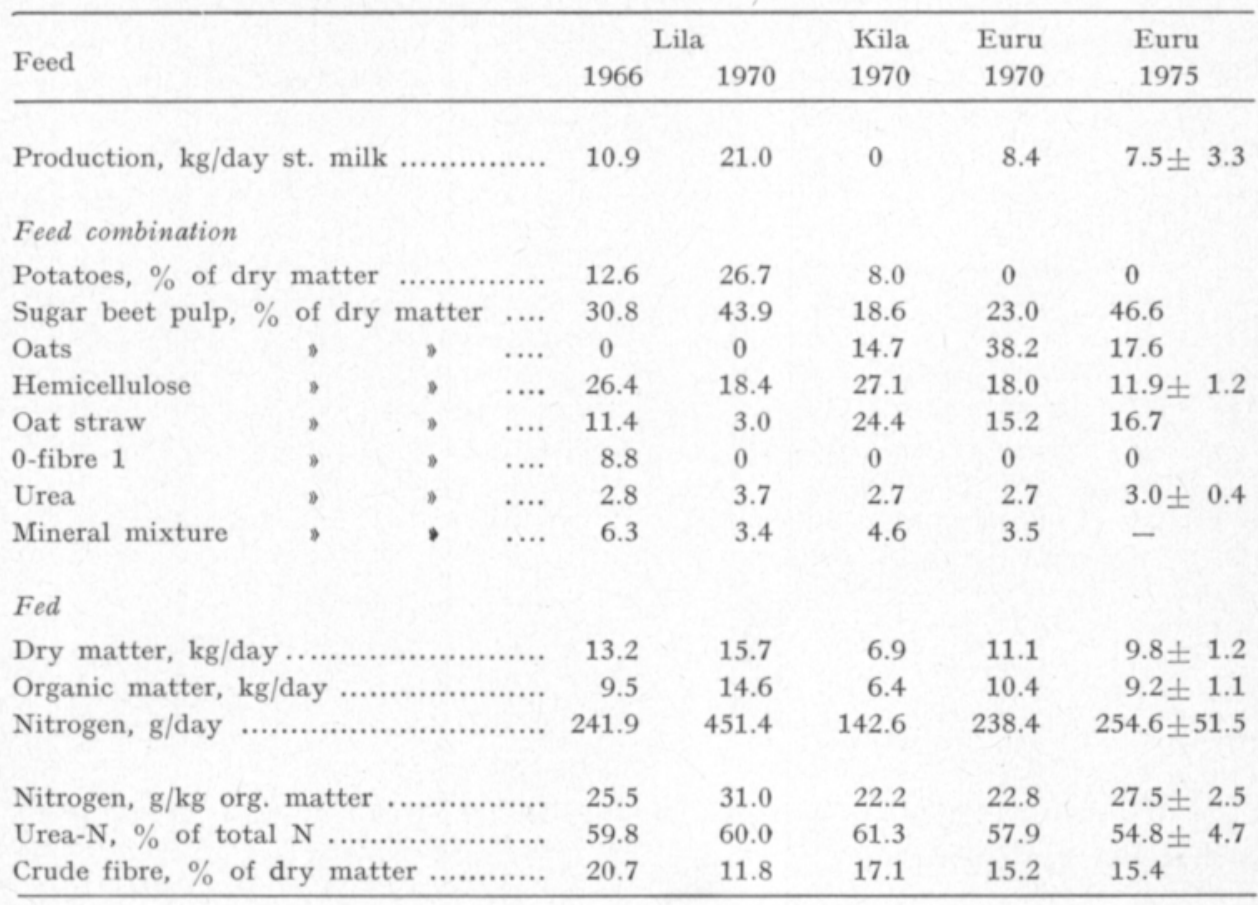

Table 7. The digestibility of the feed mixture and the nitrogen balance tests with ULP-cows.

\begin{tabular}{|c|c|c|c|c|c|}
\hline & $\begin{array}{c}\text { Dry } \\
\text { matter } \\
\%\end{array}$ & $\begin{array}{c}\text { Organic } \\
\text { matter } \\
\%\end{array}$ & $\begin{array}{l}\text { Nitrogen } \\
\%\end{array}$ & $\begin{array}{l}\text { Crude } \\
\text { fibre } \\
\%\end{array}$ & $\begin{array}{l}\text { Nitrogen } \\
\text { balance } \\
\text { g/day }\end{array}$ \\
\hline Lila (milk 10.9) ......... & 64.9 & 65.7 & 64.7 & 56.7 & \\
\hline Lila $(, 21.0) \ldots \ldots \ldots$ & 75.1 & 77.4 & 75.4 & 57.0 & \\
\hline Kila $(, 0) \ldots \ldots \ldots$ & 71.8 & 74.6 & 75.6 & 63.0 & \\
\hline Euru $(, 8.4) \ldots \ldots \ldots .$. & 70.4 & 73.1 & 64.3 & 54.6 & \\
\hline $\begin{array}{l}\text { Euru }(, \quad 7.5 \pm 3.3) \\
\text { three tests } \ldots . \ldots . \ldots . \ldots . . .\end{array}$ & $70.6 \pm 1.9$ & $73.1 \pm 1.5$ & $70.6 \pm 4.5$ & $67.9 \pm 7.4$ & $+39.4 \pm 16.4$ \\
\hline $\begin{array}{l}\text { Mean value } \\
\text { in all tests } \ldots \ldots \ldots \ldots \ldots \ldots . . . . .\end{array}$ & $70.6 \pm 3.2$ & $72.9 \pm 3.7$ & $71.2 \pm 4.9$ & $61.2 \pm 6.8$ & \\
\hline
\end{tabular}




\title{
REFERENCES
}

Andersen, A. C. 1934. Die Futtermittelanalyse und die Bestimmung der Verdaulichkeit der Futtermittel. Skand. Arch. Physiol. 69: 33-58.

BeEt, A. E. 1955. Potassium permanganate in the Kjeldahl method for the determination of nitrogen in organic substances. Nature 175: 513-514.

Etrala, T. \& Kreula, M. 1976. Milk Production on Low-protein, Urea-rich Feed. Acta Agr. Scand. 26: 33-39.

HirsJärvi, V.P. \&ANDERSEN, L. 1954. Ubber die Rohfaserbestimmung. Z. anal.Chem.141:348-361.

Raleigh, R. J. \& Wallace, J. D. 1963. Effect of urea at different nitrogen levels on digestibility and performance of growing steers fed low quality flood meadow roughage. J. Anim. Sci. 22: 330-334.

SaArinen, P., Jensen, J. \& Alhojärvi, J. 1959. On the digestibility of high yield chemical pulp and its evaluation. Acta Agr. Fenn. 94:41-62.

Schiemann, R., Henseler, G., Jentsch, W. \& Wittenburg, H. 1974. Die Verwertung der Futterenergie für die Milchproduktion. Arch. Tierernähr. 24: 105-137.

Virtanen, A. I. 1963. Produktion der Kuhmilch ohne Protein mit Harnstoff und Ammoniumsalzen als Stickstoffquelle und gereinigten Kohlenhydraten als Energiequelle. Biochem. Z. $338: 443-453$.

- - 1964. Versuche über Milchproduktion ohne Protein unter ausschliesslicher Verwendung von Harnstoff und Ammoniumstickstoff. Nach. Giessener Hochsch. Ges. 33: 73-89.

- -1966 . Milk production of cows on protein-free feed. Science 153: 1603-1614.

- -1967 . New views in cattle feeding; normal concentrates replaced by urea and hemicellulose syrup prepared from wood. Agrochimica 11: 289-301.

- - Etrala, T. \& Mäkrnen, S. 1972. Milk production of cows on purified protein-free feed with urea and ammonium salts as the only nitrogen source and on non-purified feed with rising amounts of true protein. Festskr. 70. årsdag. Prof. K. Breirem 1972. p. 249-275. Gjovik.

- - \& Lampila, M. 1962. Production of cow's milk on purified nutrients without proteins. Suom. Kemistilehti B 35: 244 .

Ms received February 2, 1977

\section{SELOSTUS}

\section{Lypsylehmien rehujen sulavuudet ja typpitaseet urean ollessa ainoana tai osittaisena typenlähteenä}

\author{
M. Kreula ja T. Ettala \\ Biokemiallinen Tutkimuslaitos, Kalevankatu 56 b, 00180 Helsinki 18
}

Sulavuus- ja typpitasekokeita on tehty sekä puhdistetulla, proteiinittomalla ruokinnalla olleilla lehmillä (0-ruokinta ja 0-lehmät), joilla urea on ollut ainoana typenlähteenä että lehmillä, joiden rehut ovat sisältäneet vähän proteiinia ja runsaasti ureaa (ULP-ruokinta ja ULPlehmät). Tavanomaisten vähän proteiinia sisältävien rehujen lisäksi on ULP-ruokinnassa ollut energialähteenä puunjalostusteollisuuden jätteitä ns. hemiselluloosaa ja ns. 0-kuitua.

Lannan määrän toteamiseksi on käytetty indikaattorina kromioksidia tai kerätty kaikki lanta talteen. Typpitaseen selville saamiseksi on kerätty joko lanta ja virtsa yhdessä talteen, jolloin kromioksidilla on määritetty lannan määrä tai lanta ja virtsa on kerätty erikseen talteen.

0 -lehmillä on typen ( $=$ urea-N) keskimääräinen sulavuus ollut $67.0 \pm 5.2 \%$, kuiva-aineen $73.9 \pm 5.1 \%$ ja orgaanisen aineen $76.6 \pm 5.1 \%$.

ULP-lehmillä kokonaistypen sulavuus on ollut keskimäärin $71.2 \pm 4.9 \%$ ja ureatypen vaihdellut välillä $70-86 \%$. Hemiselluloosan keskimääräiseksi sulavuudeksi on saatu $83 \%$ ja sulfiittiselluloosateollisuuden jätekuidun (0-kuitu 2) $80 \%$.

Typpitase on ollut kaikissa kokeissa positivinen, 0-lehmillä $+20.4 \pm 20.6 \mathrm{~g}$ ja ULP-lehmillä $+39.4 \pm 16.4 \mathrm{~g}$ päivässä. 